\title{
研究論文
}

\section{The Propagation of Neutron Multiplication in the Pulsed Neutron Injected Cores}

\author{
By Toshikazu SHIBATA*, Tokuo SUITA* and Fumio HIRAYAMA**
}

\begin{abstract}
By using an analog computer two-group calculations were carried out on the transient behaviors of the neutron multiplication in bare cores of the swimming pool type reactor, which is caused by a short burst of fast neutrons on the central plane. The "propagation" of neutron multiplication from the source plane to the outer boundaries have been found. The propagation velocity of neutron multiplication decreases with the increasing core size up to the critical. The maximum thermal neutron flux caused by the pulsed neutron injection has not a strong dependency on the core size which is a drastic character of the steady flux.
\end{abstract}

\section{INTRODUCTION}

It is of interest for reactor physics or engineering to know the time behavior of neutron flux in the reactor core after the pulsed neutron injection. If the size of core is close to the critical, a large number of neutron multiplications will result, and it may be used as a neutron amplifier ${ }^{(1)}$. The time behavior of the flux is very complicated in the case of the pulsed neutron injection. The decay part of the time behavior has been employed for determination of the buckling of the core ${ }^{(2)}$, while the growing part has not been investigated experimentally yet. Neither measurement with quick response nor exact analysis of the growing flux has been carried out.

The authors are planning to construct the pulsed reactor using the pulsed neutron injection by an accelerator. In this experiment, it is necessary to know the time behavior of neutron flux for obtaining a fine pulsed neutron flux. The analog computer was used for the two-group calculation as a first approach to the problem.

The analysis of the rapid phenomena especially in the light water moderated core should be based on the transport theory. However, it is very difflcult to obtain the accurate solution of the transport equation even in the simplified system. Hence the approx- imate solutions of the problem in the twogroup diffusion approach were treated in this work.

As the result, the "propagation" of neutron multiplication from the source through the core has been concluded.

\section{Basic Equations}

The two-group diffusion approach is used in this paper. The basic equations adopted are as follows:

$$
\begin{aligned}
& D_{1} \nabla^{2} \phi_{1}(\boldsymbol{r}, t)-\Sigma_{1} \phi_{1}(\boldsymbol{r}, t)+k \Sigma_{2}(1-\beta) \phi_{2}(\boldsymbol{r}, t) \\
& \quad+\lambda C(\boldsymbol{r}, t)+S(\boldsymbol{r}, t)=\frac{\partial n_{1}(\boldsymbol{r}, t)}{\partial t} \\
& D_{2} \nabla^{2} \phi_{2}(\boldsymbol{r}, t)-\Sigma_{2} \phi_{2}(\boldsymbol{r}, t)+\sum_{1} \phi_{1}(\boldsymbol{r}, t) \\
& \quad=\frac{\partial n_{2}(\boldsymbol{r}, t)}{\partial t} \\
& \frac{\partial C(\boldsymbol{r}, t)}{\partial t}=-\lambda C(\boldsymbol{r}, t)+\left(\frac{k \beta}{p}\right) \sum_{2} \phi_{2}(\boldsymbol{r}, t)(3)
\end{aligned}
$$

where the subscript 1 indicates the fast, and 2 the thermal group. All the symbols in the equations are to be read as usual, i.e. ;

$\lambda$ : average decay constant of delayed neutrons

$D_{1}, D_{2}$ : diffusion coefficients

$\phi_{1}, \phi_{2}$ : neutron fluxes

$n_{1}, n_{2}$ : neutron densities

* 柴田俊一, 吹田徳雄。College of Engng., Osaka Univ. (大阪大学 工学部)

** 平山文夫。Univ. of Michigan 
$C:$ concentration of the precursor

$k$ : multiplication constant in the infinite medium

$P$ : the resonance escape probability

$\beta$ : the fraction of delayed neutrons

$\boldsymbol{r}:$ the position vector

$t$ : time

$S:$ the neutron source intensity

The time variations of the neutron fluxes after the pulsed neutron injection are calculated under appropriate boundary conditions. For simplicity, a bare infinite slab core is considered in this paper.

\section{Basic Data for Calculations}

The computation by analog computer was carried out for the following basic data which were taken from the Ford Nuclear Reactor of the Univ. of Michigan $^{(3)}$.

$$
\begin{aligned}
& D_{1}=1.247 \mathrm{~cm} \\
& D_{2}=0.220 \mathrm{~cm} \\
& \Sigma_{1}=0.0201 \mathrm{~cm}^{-1} \\
& \Sigma_{2}=0.0814 \mathrm{~cm}^{-1} \\
& \beta=0.0075 \\
& \lambda=00787 \mathrm{sec}^{-1} \\
& k=1.6 \\
& p=1
\end{aligned}
$$

The critical thickness of the infinite slab core should be $32.2 \mathrm{~cm}$.

\section{Programming}

The low speed analog computer made by the Pace Electronics Co. was used for computations. For simplicity, one dimensional model was adopted. The plane neutron source is assumed to be placed at the center $x=0$ of the slab. The right half of the slab core is shown schematically in Fig. 1. Basic equations in this case are as follows :

$$
\begin{gathered}
D_{1} \frac{\partial^{2}}{\partial x^{2}} \phi_{1}(x, t)-\Sigma_{1} \phi_{1}(x, t)+k \Sigma_{2}(1-\beta) \times \\
\phi_{2}(x, t)+\lambda C(x, t)+S(x, t)=\frac{1}{v_{1}} \frac{\partial \phi_{1}(x, t)}{\partial t} \\
D_{2} \frac{\partial^{2}}{\partial x^{2}} \phi_{2}(x, t)-\Sigma_{2} \phi_{2}(x, t)+\Sigma_{1} \phi_{1}(x, t) \\
\quad=\frac{1}{v_{2}} \frac{\partial \phi_{2}(x, t)}{\partial t} \\
\frac{\partial C(x, t)}{\partial t}=-\lambda C(x, t)+\frac{k \beta}{p} \Sigma_{2} \phi_{2}(x, t)
\end{gathered}
$$

where $v_{1}$ and $\tau_{2}$ are the average neutron velocities of the fast and thermal group respectively.

The boundary conditions are

$$
\frac{\partial \phi_{1}(x, t)}{\partial x}=0, \frac{\partial \phi_{2}(x, t)}{\partial x}=0 \text { at } \quad x=0
$$

and

$$
\phi_{1}(x, t)=0, \phi_{2}(x, t)=0 \quad \text { at } \quad x=H
$$

where $x=H$ is the extrapolated boundary of the core considered. The initial conditions used are:

$$
\phi_{1}(x, 0)=\phi_{2}(x, 0)=0, \text { at } \quad t=0
$$

Several values of $H$ up to the critical size are specified for the computations. The values of $v_{1}$ and $v_{2}$ are determined as follows: $v_{2}$ is the average neutron velocity of the thermal group and $v_{1}$ corresponds to the average of the lethergy of the fast neutrons*, or

$$
\frac{1}{2} M v_{1}^{2}=\sqrt{E_{0} E_{\mathrm{th}}}
$$

where $M$ is the mass of neutron, $E_{0}$ and $E_{\text {th }}$ are the energies of fission and thermal neutrons respectively.

The time scale $\tau$ of the computer was selected as

$$
\tau=10^{5} \cdot t
$$

where $t$ is the actual time. The selection is appropriate for programming and computing in the problem.

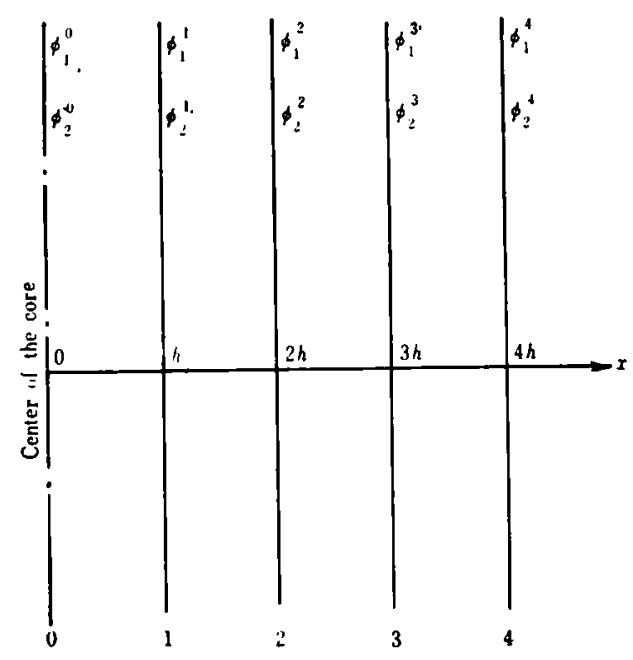

Fig. 1 Division of the core for approximate differenciation

* The effects of neutron absorption were neglected. 
Under these specifications several terms in the basic equations become too small for programming and are neglected. They include those of the delayed neutrons, which have to be retained only in the phenomena in time scale larger than milliseconds.

The spatial differenciations are replaced by the finite differences by dividing the slab equidistantly ${ }^{(4)}$. In this paper the right half of the slab core is divided into 4 parts as shown in Fig. 1.

Under these approximations, the machine equations become

$$
\begin{aligned}
& \phi_{1}{ }^{0}=-\int\left\{-\left(2 a_{1}\right) \phi_{1}{ }^{1}+\left(2 a_{1}+a_{2}\right) \phi_{1}{ }^{0}-a_{3} \phi_{2}{ }^{0}\right. \\
& \left.-a_{4} S\right\} d \tau \text {, } \\
& \phi_{1}{ }^{1}=-\int\left\{-a_{1} \phi_{1}{ }^{0}-a_{1} \phi_{1}{ }^{2}+\left(2 a_{1}+a_{2}\right) \phi_{1}{ }^{1}\right. \\
& \left.-a_{3} \phi_{2}{ }^{1}\right\} d \tau \text {, } \\
& \phi_{1}{ }^{2}=-\int\left\{-a_{1} \phi_{1}{ }^{1}-a_{1} \phi_{1}{ }^{3}+\left(2 a_{1}+a_{2}\right) \phi_{1}{ }^{2}\right. \\
& \left.-a_{3} \phi_{2}^{2}\right\} d \tau \text {, } \\
& \phi_{1}^{3}=-\int\left\{-a_{1} \phi_{1}{ }^{2}+\left(2 a_{1}+a_{2}\right) \phi_{1}{ }^{3}-a_{3} \phi_{2}{ }^{3}\right\} d \tau \text {, } \\
& \phi_{2}{ }^{0}=-\int\left\{-2 b_{1} \phi_{2}{ }^{1}+\left(2 b_{1}+b_{3}\right) \phi_{2}{ }^{0}-b_{2} \phi_{1}{ }^{0}\right\} d \tau \text {. } \\
& \phi_{2}{ }^{1}=-\int\left\{-b_{1} \phi_{2}{ }^{0}-b_{1} \phi_{2}{ }^{2}+b_{2} \phi_{1}{ }^{1}\right. \\
& \left.+\left(2 b_{1}+b_{3}\right) \phi_{2}{ }^{1}\right\} d \tau \text {. } \\
& \phi_{2}{ }^{2}=-\int\left\{-b_{1} \phi_{2}{ }^{1}-b_{1} \phi_{2}{ }^{3}-b_{2} \phi_{1}{ }^{2}\right. \\
& \left.+\left(2 b_{1}+b_{3}\right) \phi_{2}{ }^{2}\right\} d \tau \text {, } \\
& \phi_{2}{ }^{3}=-\int\left\{-b_{1} \phi_{2}{ }^{2}-b_{2} \phi_{2}{ }^{3}+\left(2 b_{1}+b_{3}\right) \phi_{2}{ }^{3}\right\} d \tau \text {, }
\end{aligned}
$$

where $\phi_{1}{ }^{i}$ and $\phi_{2}{ }^{t}$ are the fast and the neutron fluxes at the $i$ th boundary respectively, and $a_{f}$ and $b_{f}$ are the constants given in terms of the nuclear constants and the core size as follows:

$$
\begin{aligned}
& a_{1}=\frac{D_{1} v_{1}}{h^{2}} \cdot \frac{1}{10^{5}} \\
& a_{2}=\Sigma_{1} v_{1} \cdot \frac{1}{10^{5}} \\
& a_{3}=\Sigma_{2} k v_{1}(1-\beta) \cdot \frac{1}{10^{5},} \\
& a_{4}=v_{1} \cdot \frac{1}{10^{5}} \\
& b_{1}=\frac{D_{2} v_{2}}{h^{2}} \cdot \frac{1}{10^{5}}, \\
& b_{2}=\sum_{1} v_{2} \cdot \frac{1}{10^{5}},
\end{aligned}
$$

$$
b_{3}=\Sigma_{2} v_{2} \cdot \frac{1}{10^{5}} \text {, }
$$

where $h=\frac{H}{4}$.

Now the typical connection diagrams are shown in Fig. 2.
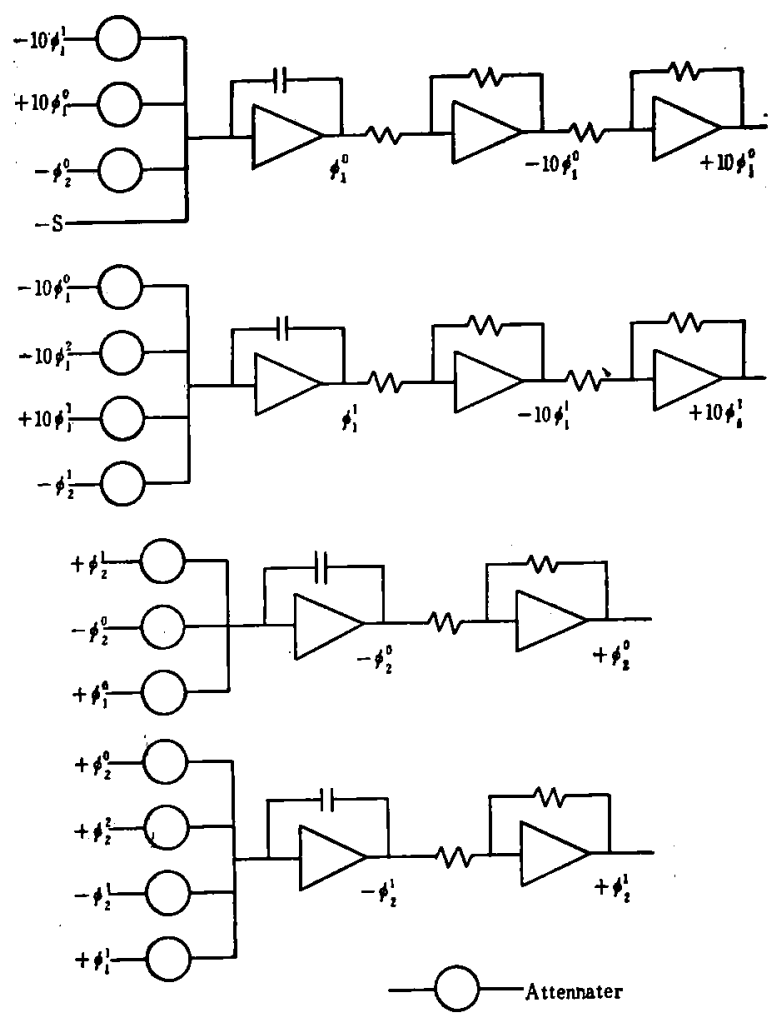

Fig. 2 Block diagrams of the typical computer circuits

The voltage pulse corresponding to the neutron pulse applied to the center of the core is generated by a simple flip-flop pulse generator provided with the clamp circuit for eliminating the negative over shoot of the pulse. The intensity $S$ of the neutron source is connected with the pulse height through

$$
\begin{aligned}
S & =\frac{1}{a_{4}} \times(\text { pulse height }) \\
& \cong 7.04 \times 10^{-3} \times(\text { pulse height })
\end{aligned}
$$

where the pulse height is measured in volt, and $S$ is measured in $\mathrm{n} / \mathrm{cm}^{2} \cdot$ sec.

\section{Results}

\section{Step-function source}

When the step-function source is applied to the core, the thermal fluxes in the core 
grow with time as shown in Fig. 3

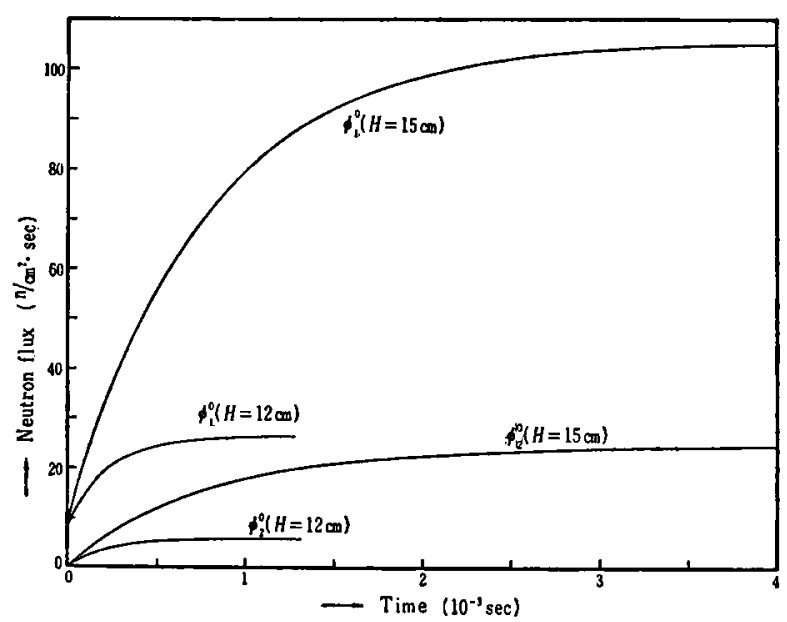

Fig. 3 Time behaviors of fluxes after unit functional neutron source $\left(\mathrm{n} / \mathrm{cm}^{2} \cdot \mathrm{sec}\right)$

After sufficiently long time the fluxes attain the steady values, which varies with the core size as shown in Fig. 4.

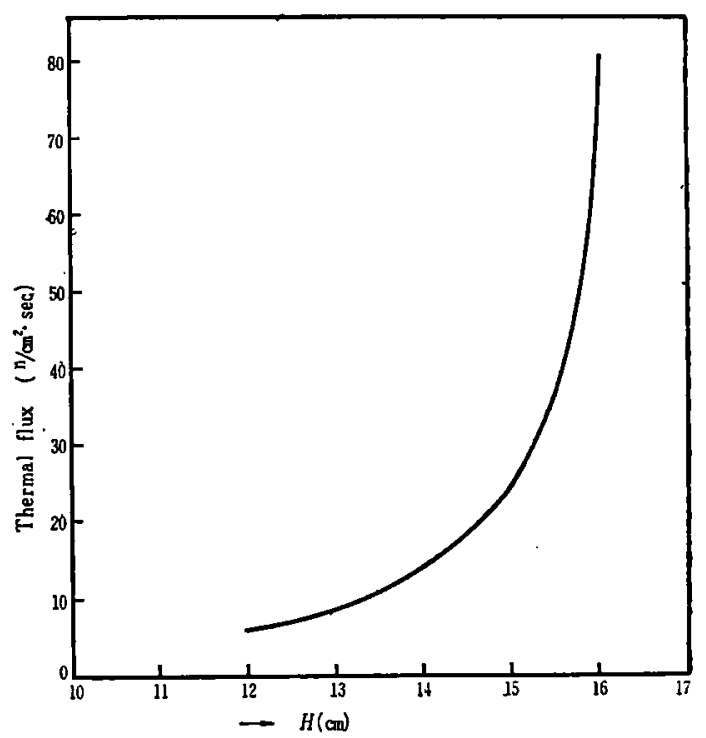

Fig. 4 Steady value of thermal flux per unit neutron $\operatorname{source}\left(\mathrm{n} / \mathrm{sec} / \mathrm{cm}^{2}\right)$ vs. core size

As mentioned in the preceding section, all the terms concerning the delayed neutrons are neglected in this case. Therefore the time constants of neutron multiplication and decay differ from the ordinary period of the core.

\section{Pulsed neutron source}

The pulse of $6 \mu \mathrm{sec}$ width in computer time scale was used as the source term.

The time behaviors of the neutron fluxes
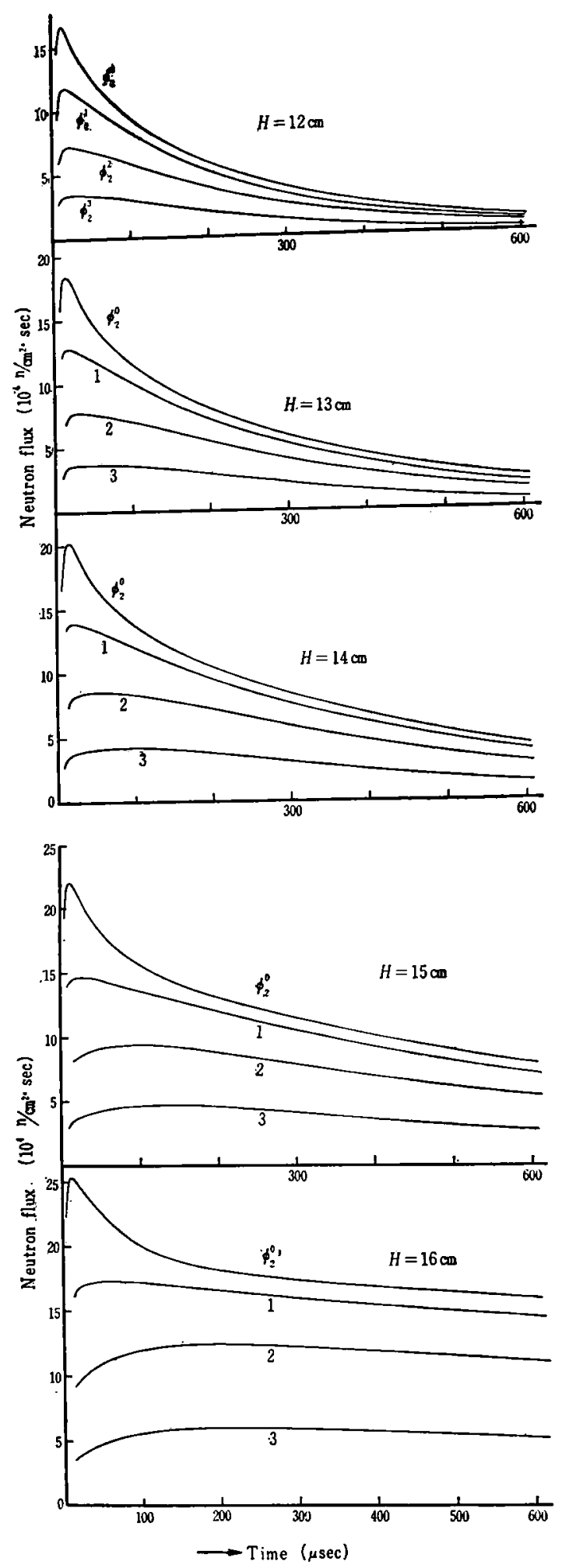

Fig. 5 Fluxes as functions of time after unit source neutron $\left(1 \mathrm{n} / \mathrm{cm}^{2} \cdot \mathrm{sec}\right)$ injections

for various core sizes are shown in Fig. 5 . At the distant points from the source the maximum thermal neutron fluxes are obtained 
with some delay after the neutron injection. The delay time depends on the distance from the source and on the core size as shown in Fig. 6.

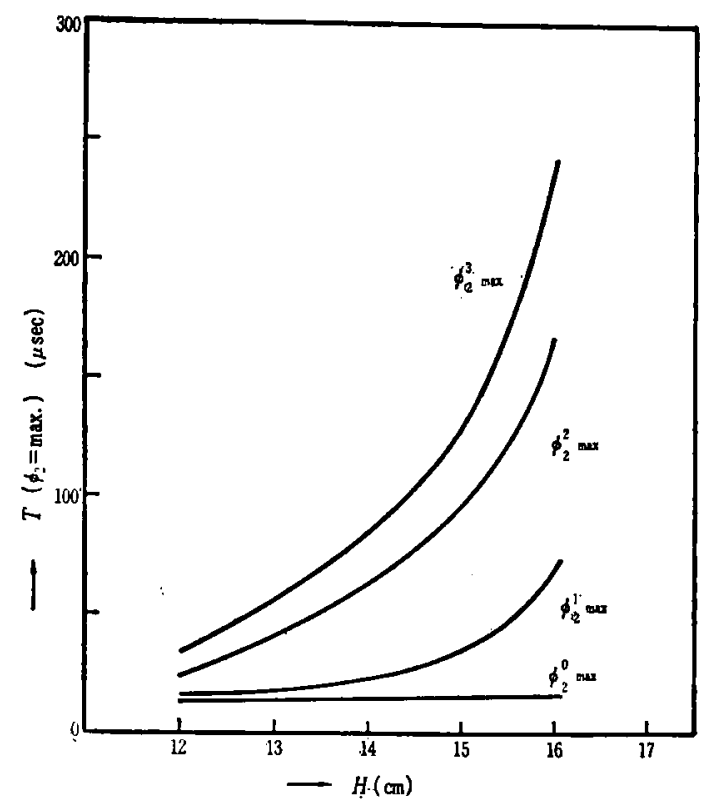

Fig. 6 The time at which the thermal fluxes become the maximum as functions of the core size

For larger distance, it takes longer time for the flux to reach the maximum. These phenomena are known partly as the oscillation of the flux ${ }^{(5)(6)}$. In this case, however, the term "propagation" is believed to be more appropriate since the time of arrival of the maximum multiplication to the outer surface is of interest. The propagation time increases with the core size approaching the critical.

\section{Discussions}

The analysis of the time behavior of the fluxes in the core is very important in the experiments of pulsed neutron. In very short time after the pulse injection, the neutron flux distribution differs from the steady one, while the steady distribution is assumed usually in the analysis of the pulse experiment. Our result gives a solution to the problem.

There are some points to be improved in the future works :

In the first place, the present computations were done in the two-group diffusion approach. However, the velocity of propagation depends strongly on the neutron velocity, hence the multigroup approach should take the place of the present one. The second, the actual core has not the shape of slab. However, only the coefficients of the machine equations depend on the core shape and no significant alteration will be needed for the actual core. The third, the reflector will affect the propagation. Furthermore, the effect of delayed neutrons was neglected in the present work.

It should be noted that the maximum value of the flux depends weakly on the core size while the decay constant of the flux and the steady value of the flux for continuous source have strong dependency on the core size.

Moreover, a slightly modified computation would serve to estimate the magnitude of the reactor power fluctuation caused by the spontaneous neutron injection or the local high neutron flux.

\section{Summary}

The time behaviors of the neutron fluxes at various points in the swimming pool type reactor core after pulsed neutron injection were obtained by an analog computer in the two-group diffusion approach.

The neutron multiplication propagates from the source through the multiplying medium, and the velocity of the propagation depends on the size of the system. The neutron flux distribution should be the steady one at certain time after the pulsed neutron injection. The propagation time amounts to several hundreds microseconds in some cases close to the critical. Therefore, the very short pulse operation could never be performed for large core close to the critical.

(Received December 14, 1960)

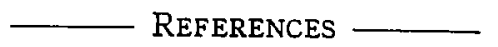

(1) L. B. Borst: Phys. Rev., 107, 905 (1957).

(2) S. C. Fultz: Nucl. Sci. Engng., 6, 313 (1959) ; F. A. KLOVERSTROM, T. T. Komoto: UCRL-5477, (1959).

(3) O. Riseng, P. Stone, C. Velez: Thesis, Univ. Michigan, (1956).

(4) G. A. KORN, T. M. KORN: "Electronic Analog 
Computers", (1956), McGraw-Hill.

(5) A. M. Weinberg, H. C. Schweinler: Phys. Rev., 74, 851 (1948).

(6) A. M. Weinberg. E. P. Wigner: "The Physical Theory of Neutron Chain Reactors", p. 436 (1958), The Univ. of Chicago Press.

\section{パルス中性子を入射した炉心における 中性子増殖の伝播}

柴田俊一, 吹田徳雄, 平山文夫

種々の寸法の水泳プール型炖心にパルス状中性子を 入射した場合，その中性子増倍は中性子源より離れた ところほど入射より遅れて起こる。中性子增幅器とし ての臨界末満炻心に中性子を入射してパルス作動をさ せる場合，炉物理に打けるパルス法を用いる種々の実 験の場合など，この現象はかなり考虑される必要が
る。現在の段階では実験は困難なので理論的に計算し一 た。このよ5な短い時間の現象は本来, 輸送理論によ って解くべきであるがここでは二群拡散理論によっ て近似を試みた。計算にはアナログ計算機を用いた。 中性子が入射されてから，ある点の中性子束が極大 に達するまでの時間は，ての点の中性子源からの距離: に依存して変わるので,この時間を一応中性子増倍の 伝播時間と考える。この伝播時間は同じ型の炉心では 寸法が臨界に近つくくに従って大きくなる。またバルス 中性子の入射によって得られる中性子束の極大值は， 定常中性子源の場合と異なり，炉心寸法にはあまり依 存しない。たたし減衰の有様は炉心寸法によって著し く異なる。この結果, 中性子增幅器としてのパルス運 転には比較的小さな炉心を使う方が中性子束の極大值 はあまり小さくならす，減衰の速い，鋭いパルスが得 られるため有利なことがわかった。また偶発的な中性. 子入射，あるいは局部的に高い中性子束等に起因する 原子炉出力の fluctuation の大きさもこの計算の僅か. な変形から算定することができるであろ5。

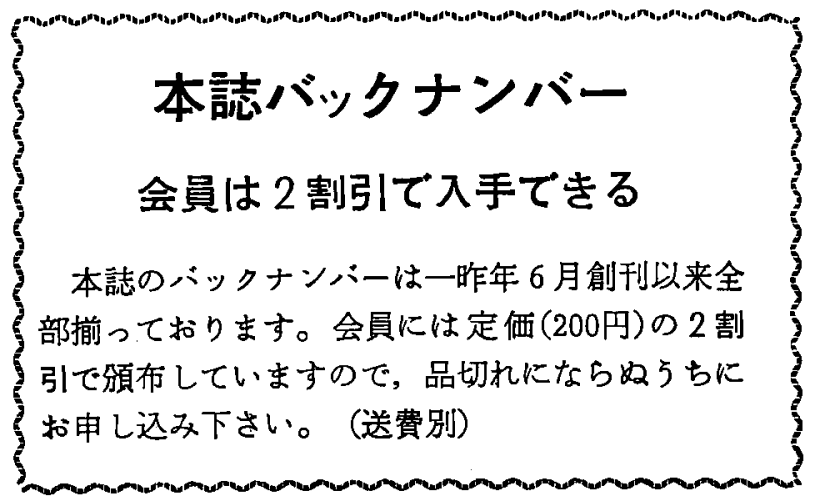

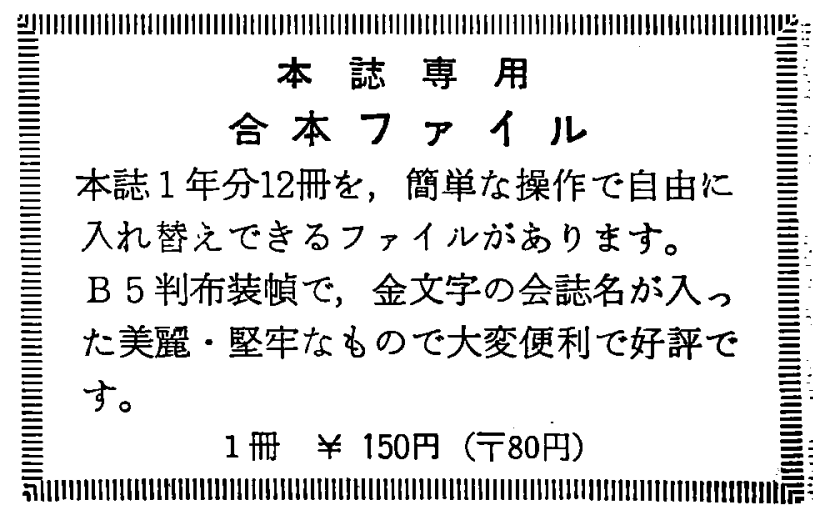

